SJ Quinney College of Law, University of Utah Utah Law Digital Commons

Utah Law Faculty Scholarship

Utah Law Scholarship

$5-2017$

\title{
The Anti-Suit Injunction - A Transnational Remedy for Multi-Jurisdictional SEP Litigation
}

Jorge L. Contreras

University of Utah, jorge.contreras@law.utah.edu

Michael A. Eixenberger

S.J. Quinney College of Law, University of Utah

Follow this and additional works at: http://dc.law.utah.edu/scholarship

Part of the Intellectual Property Law Commons

\section{Recommended Citation}

The Anti-Suit Injunction - A Transnational Remedy for Multi-Jurisdictional SEP Litigation (May 10, 2017). Cambridge Handbook of Technical Standardization Law - Patent, Antitrust and Competition Law (Jorge L. Contreras, ed., 2017, Forthcoming)

This Book Chapter is brought to you for free and open access by the Utah Law Scholarship at Utah Law Digital Commons. It has been accepted for inclusion in Utah Law Faculty Scholarship by an authorized administrator of Utah Law Digital Commons. For more information, please contact valeri.craigle@law.utah.edu. 
CAMBRIDGE HANDBOOK OF TECHNICAL STANDARDIZATION LAW - ANTITRUST, COMPETITION AND PATENT LAW (Jorge L. Contreras, ed., Cambridge Univ. Press 2017, forthcoming)

\section{ChAPTER 27}

\section{THE ANTI-SUIT INJUNCTION - A TRANSNATIONAL REMEDY FOR MULTI- JURISDICTIONAL SEP LITIGATION}

Jorge L. Contreras* and Michael A. Eixenberger ${ }^{* *}$

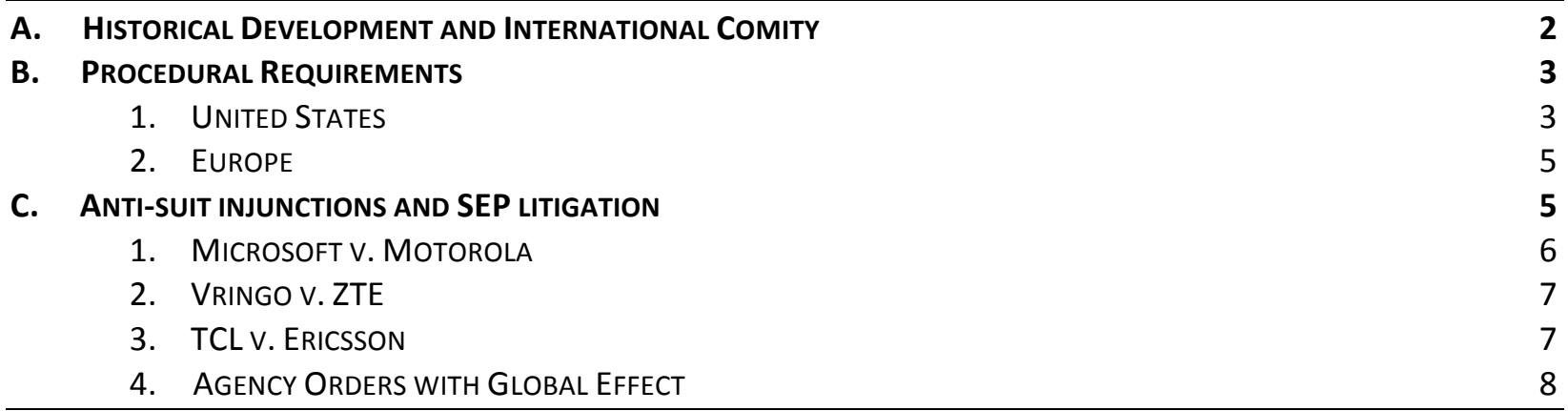

Litigation concerning standards-essential patents (SEPs) has become increasingly global, with parallel litigation occurring over the same issues in multiple jurisdictions throughout North America, Europe and Asia. ${ }^{1}$ As a result, litigants have sought mechanisms to coordinate these actions both to manage costs and to avoid inconsistent and incompatible results. One littleknown procedural mechanism that has long been available to manage multi-jurisdictional litigation, and which is growing in popularity in SEP disputes, is the anti-suit injunction.

An anti-suit injunction is an interlocutory remedy issued by a court in one jurisdiction which prohibits a litigant from initiating or continuing parallel litigation in another jurisdiction or jurisdictions. Anti-suit injunctions thus contain litigation costs and reduce the likelihood of inconsistent results by ensuring that issues are resolved in one jurisdiction before they are litigated elsewhere. ${ }^{2}$ In the standards context, anti-suit injunctions can be particularly powerful tools for prospective licensees alleging that SEP holders have failed to comply with their FRAND licensing obligations. Specifically, a court reviewing a SEP holder's compliance with a FRAND licensing commitment may issue an anti-suit injunction to prevent the SEP holder from bringing foreign patent infringement claims (including injunctions against the sale of infringing products) until the FRAND licensing dispute has been resolved in the issuing jurisdiction.

\footnotetext{
* Associate Professor, University of Utah S.J. Quinney College of Law. Please send comments, corrections and suggestions to jorge.contreras@law.utah.edu.

J.D. Candidate 2017 and Quinney Fellow, Center for Law and Biomedical Sciences, University of Utah S.J. Quinney College of Law, Salt Lake City, UT.

${ }^{1}$ For example, Apple and Samsung litigated their smartphone patent dispute (including issues relating to standardsessential patents) in the U.S. (both in the Northern District of California and International Trade Commission), Germany, France, Italy, the Netherlands, UK, Korea, Japan and Australia. See discussions of this case in Chapters X, Y and Z. [ITC, Injunctions, EU Injunctions, Japan, Korea].

2 These benefits may be realized even in the absence of formal res judicata effect of judicial decisions from one jurisdiction to another.
} 
This chapter discusses the historical development and procedural requirements for anti-suit injunctions in both the United States and Europe. It also reviews recent SEP cases in which anti-suit injunctions have been granted, including Microsoft v. Motorola, Vringo v. ZTE and TCL v. Ericsson.

\section{A. Historical Development and International Comity}

The anti-suit injunction is an equitable and discretionary form of relief that can be traced to at least the fifteenth century in England. The first anti-suit injunctions were writs of prohibition issued by the Court of the King's Bench and the Court of Chancery to stay pending proceedings in the ecclesiastical courts. ${ }^{3}$ These writs were issued to establish and enforce jurisdictional boundaries between the royal courts and the ecclesiastical courts. ${ }^{4}$ Such writs were viewed as necessary because the ecclesiastical courts held an expansive view of the subject matter within their own jurisdiction, a view that occasionally conflicted with the view of the royal courts. ${ }^{5}$

Although writs of prohibition were initially used by the royal courts to limit the subject matter jurisdiction of the ecclesiastical courts, by the sixteenth century they assumed a more equitable character. The English Court of Chancery began issuing writs of prohibition, known as "common injunctions," to prevent parties from bringing suit in the common law courts when "doing so would be considered contrary to good conscience."6 Initially, the Chancery courts only granted common injunctions to bar litigation in other English courts. However, by the nineteenth century their use was expanded beyond England. First, they were granted to prevent litigation in Scotland, Ireland and other British Colonies, ${ }^{7}$ and were eventually expanded to foreign courts. ${ }^{8}$

For example, in Lord Portarlington $v$. Soulby, Soulby brought a claim in Ireland against Lord Portarlington, to collect gambling debts..$^{9}$ Lord Portarlington sought an anti-suit injunction in England to prevent Soulby from maintaining the Irish suit. Soulby argued that the English courts could not interfere with the Irish courts. ${ }^{10}$ In granting the anti-suit injunction, the Chancery court reasoned that common injunctions could be granted equally within England and abroad because they were directed at the parties, as well as the specific court. ${ }^{11}$

In the United States, anti-suit injunctions began as domestic tools to curb parallel litigation in the courts of different states, ${ }^{12}$ but their use was subsequently expanded to apply to actions in foreign jurisdictions. By the nineteenth century, the Supreme Court acknowledged a U.S. court's ability "to restrain persons within its territorial limits and under its jurisdiction from doing anything abroad, whether the thing forbidden be ... the institution or the prosecution of an action in a foreign court."13

\footnotetext{
${ }^{3}$ Trevino de Coale 1999, 80.

${ }^{4}$ Bermann 1990, 594; Helmholz 1975, 1011.

${ }^{5}$ Helmholz 1975, 1011. For example, the ecclesiastical courts claimed jurisdiction to resolve all breach of contract claims formalized by means of an oath. In response, the royal courts issued writs of prohibition noting the ecclesiastical courts had jurisdiction to punish a man for perjury, but they did not have jurisdiction to hear all lay contract claims. Id.

${ }_{7}^{6} I$.

${ }^{7}$ See, e.g., Lord Portarlington v. Soulby (My \& K. 1834).

${ }^{8}$ See, e.g., Hope v. Carnegie (Ch.App. 1866).

${ }_{10}$ Lord Portarlington v. Soulby (My \& K 1834).

${ }^{10}$ Id.

${ }^{11} / d$.

${ }^{12}$ Bermann 1990, 594-96 (discussing the impact of the Full Faith and Credit Clause of the U.S. Constitution on sisterstate anti-suit injunctions in the U.S.).

${ }^{13}$ Cole v. Cunningham (U.S. 1890, p.116-17).
} 
Gage v. Riverside Trust Co. is one of the earliest reported foreign anti-suit injunction cases in the United States. ${ }^{14}$ Gage filed a loan securities suit in a California Federal Court. While the proceedings were pending, Riverside Trust Co. filed a parallel suit in the High Court of Justice in England. ${ }^{15}$ Relying on principles of equity, the California court enjoined the English proceedings. The court noted that its proceedings began before the suit in England and it had undoubted authority to control the actions of individuals within its territorial limits. ${ }^{16}$

Although foreign anti-suit injunctions are well rooted in the common law of the United States, courts have been hesitant to grant them. ${ }^{17}$ In fact, many courts have indicated that they would rather allow parallel litigation - with all its inherent inefficiencies - than meddle with a foreign court's jurisdiction. This hesitancy has been due, in large part, to judicial deference to traditional notions of international comity. ${ }^{18}$ As explained by the Supreme Court:

Comity, in the legal sense, is neither a matter of absolute obligation, on the one hand, nor of mere courtesy and good will, upon the other. But it is the recognition which one nation allows within its territory to the legislative, executive, or judicial acts of another nation, having due regard both to international duty and convenience, and to the rights of its own citizens, or of other persons who are under the protection of its laws. ${ }^{19}$

As observed by the Supreme Court as early as 1849, though anti-suit injunctions only function against the litigants, this "does not eliminate the need for due regard to principles of international comity, because such an order effectively restricts the jurisdiction of the court of a foreign sovereign." 20 Consequently, courts in the United States and elsewhere have been sparing in their issuance of anti-suit injunctions against foreign actions. ${ }^{21}$

\section{B. Procedural Requirements}

Given this background, courts have struggled to articulate a uniform standard for deciding when to grant an anti-suit injunction. The circuit split in the United States is illustrative of this difficulty. ${ }^{22}$ This section will briefly discuss the competing standards, in the United States and in Europe, that are currently used when considering an anti-suit injunction.

\section{United States}

In the United States, three approaches have emerged for analyzing anti-suit injunctions prohibiting foreign suits. ${ }^{23}$ The three approaches are commonly referred to as the liberal, the

${ }_{14}^{14}$ Gage v. Riverside Trust Co. (C.C.S.D. Cal. 1898).

${ }^{15} / d$. at $998-99$.

${ }^{16} / d$. at 999.

17 Id.; Princess Lida of Thurn \& Taxis v. Thompson (U.S. 1939, p.466) ("[W]here the judgment sought is strictly in personam, both [courts] ... having concurrent jurisdiction, may proceed with the litigation at least until judgment is obtained in one of them which may be set up as res judicata in the other.").

${ }^{18}$ Raushenbush 1985, 1046-47.

${ }^{19}$ Hilton v. Guyot (U.S. 1895, p.163-64).

${ }^{20}$ Peck v. Jenness (U.S. 1849, p.625).

${ }^{21}$ Seattle Totems Hockey Club, Inc. v. Nat'l Hockey League (9th Cir. 1981, p.55).

${ }^{22}$ Tan 2005, 289.

${ }^{23}$ Although this chapter focuses on anti-suit injunctions directed at foreign litigation, a U.S. court may also grant a domestic anti-suit injunction, as discussed in Part A above. With respect to a domestic anti-suit injunction: (1) A court may enjoin parties "from proceeding with a concurrent action involving the same or related issues" In re Van Geuns (Fed. Cir. 1991, p.849), (2) the "first-to-file" rule "favors pursuing only the first-filed action when multiple lawsuits involving the same claims are filed in different jurisdictions," Merial Ltd. v. Cipla Ltd. (Fed. Cir. 2012, p.1299) and (3) "Under the first- to-file rule, a district court may choose to stay, transfer, or dismiss a duplicative later-filed action." Id. 
conservative, and the middle-ground approach. The liberal approach has been adopted by the Fifth, Seventh, and Ninth Circuits, while the conservative approach has been adopted by the District of Columbia, Third, Sixth and Eighth Circuits. ${ }^{24}$ The First and Second Circuits have drawn from both the conservative and the liberal approaches to create a middle-ground approach. $^{25}$

The three approaches begin with two common threshold criteria. Specifically, "(1) whether the parties are the same; and (2) whether a resolution of the U.S. action is determinative of the foreign action." 26 These threshold criteria have been construed broadly and are satisfied when the "party seeking the injunction is significantly involved in or affected by the foreign litigation" ${ }^{27}$ and the "resolution of the case before the enjoining court [would] be dispositive [for] the enjoined action." 28

Once the threshold criteria have been satisfied, the decisional methodologies of the different approaches diverge. Courts adopting the liberal approach employ a broad and flexible standard, and may grant an anti-suit injunction if any one of the following factors is sufficiently satisfied:

(1) whether the foreign action frustrates a policy of the United States; (2) whether the foreign action is "vexatious;" (3) whether the foreign action is a threat to the rem or quasi in rem jurisdiction of the U.S. court; (4) whether the proceedings in the other forum prejudice other equitable considerations; or (5) whether adjudication of the same issues in separate actions would result in delay, inconvenience, expense, inconsistency, or a race to judgment. ${ }^{29}$

At the opposite end of the spectrum, courts adopting the conservative approach emphasize that "'[c]omity dictates that foreign anti-suit injunctions be issued sparingly and only in the rarest of cases." 30 As such, circuits adopting the conservative approach usually rely exclusively on "whether the foreign action frustrates a policy of the United States" and "whether the foreign action is a threat to the rem or quasi in rem jurisdiction of the U.S. court" because these factors are critical enough to justify the compromise of deeply-held principles of international comity. ${ }^{31}$

The middle-ground approach draws from both the conservative and liberal approaches to balance comity and equity. Specifically, the approach begins by acknowledging "a rebuttable presumption against the issuance of an [anti-suit injunction]" due to comity concerns. ${ }^{32}$ However, the presumption can be overcome by analyzing the five factors elaborated by the liberal approach and weighing them against competing comity concerns. ${ }^{33}$

Finally, under all three approaches, if the court determines that the threshold criteria are satisfied and the pertinent factors weigh in favor of issuing an anti-suit injunction, the Court considers whether the anti-suit injunction's "impact on comity is tolerable."

\footnotetext{
${ }^{24}$ Tan 2005, 289.

${ }^{25}$ Ali et al. 2008, 15.

${ }^{26}$ Shaknes 2008, 9.

${ }^{27}$ Ali et al. 2008, 12.

${ }^{28}$ China Trade and Dev. Corp v. M. V. Choong Yong (2d Cir. 1987, p.36).

${ }^{29}$ Nanda et al. 2017, § 16:15.

${ }^{30}$ Goss Int'l Corp. v. Man Roland Druckmaschinen Aktiengesellschaft (8th Cir. 2007, p.359) (quoting Gau Shan Co. v Bankers Trust Co. (6th Cir. 1992, p.1354)).

${ }^{31}$ Nanda et al. 2017, § 16:15.

${ }^{32}$ Quaak v. Klynveld Peat Marwick Goerdeler Bedriffsrevisoren (1st Cir. 2004, p.18).

${ }^{33}$ Id.

${ }^{34}$ E. \& J. Gallo Winery v. Andina Licores S.A. (9th Cir. 2006, p.991).
} 


\section{Europe}

The situation in Europe is equally inconsistent, with a sharp divide between common law and civil law jurisdictions. On one hand, one commentator observes that "civil-law jurisdictions generally find anti-foreign-suit injunctions offensive, even violative of international law," 35 and seldom grant them. The English Courts, on the other hand, have continued the tradition of granting anti-suit injunctions. ${ }^{36}$

Despite the general amenability of the English courts to anti-suit injunctions, their authority to grant them has been limited by over-arching dictates of European Union ("EU”) law. Specifically, Article 27 of the Brussels Regulation adopts formal principles of comity. ${ }^{37}$ Under Article 27 , once a proceeding has begun in a court in any EU Member State, all other courts within the EU must decline jurisdiction over parallel proceedings. ${ }^{38}$ Thus, granting an anti-suit injunction to prevent a party from maintaining an earlier-filed suit in an EU Member State is inconsistent with Article 27.

But this limitation is not absolute. Historically, Article 27 was interpreted as not applying to arbitration proceedings and the European Court of Justice has held that arbitration tribunals may issue anti-suit injunctions to prevent parallel litigation in an EU Member State. ${ }^{39}$ Currently, there is a growing belief that a recent recast of the Brussels Regulation, ${ }^{40}$ which went into effect in 2015, will allow a court to issue an anti-suit injunction if the dispute involves an arbitration agreement. ${ }^{41}$ While the Brussels Regulation was originally silent as to its applicability to arbitration, the recast explicitly states that Article 27 does not apply to arbitration. ${ }^{42}$ Thus, at least while the UK remains subject to EU regulations, the ability of UK courts to issue anti-suit injunctions is generally limited to prohibiting litigants from maintaining litigation outside of the EU.

\section{Anti-suit injunctions and SEP litigation}

In recent years, litigants in SEP disputes have begun to seek anti-suit injunctions as part of their global litigation strategy. The following cases address the use of anti-suit injunctions in the SEP litigation context.

\footnotetext{
${ }^{35}$ Barceló 2007.

${ }^{36}$ Section 37(1) of the English Supreme Court Act 1981 explains "[t]he High Court may by order (whether interlocutory or final) grant an injunction or appoint a receiver in all cases in which it appears to the court to he just and convenient to do so." The English courts view anti-suit injunctions as highly fact intensive. Specifically, court's must bear "in mind that foreign proceedings may be restrained not only where they are vexatious, in the sense of being frivolous or useless, but also where they are oppressive; and also that, as Bowen L.J. observed, everything depends on the circumstances of the particular case, and new circumstances have emerged which were not, perhaps, foreseen by our Victorian predecessors." Hartley 2015.

37 Council Regulation 44/2001, on Jurisdiction and the Recognition and Enforcement of Judgments in Civil and Commercial Matters 2001 O.J. (L 12) (EC), art. 27. Specifically, Article 27 states:

1. Where proceedings involving the same cause of action and between the same parties are brought in the courts of different Member States, any court other than the court first seised shall of its own motion stay its proceedings until such time as the jurisdiction of the court first seised is established.

2. Where the jurisdiction of the court first seised is established, any court other than the court first seised

${ }_{38}$ Id. shall decline jurisdiction in favour of that court.

${ }^{39}$ Furmston 2015; Gazprom OAO v. Lietuvos Respublika (CJEU 2015).

40 Council Regulation 1215/2012, on Jurisdiction and the Recognition and Enforcement of Judgments in Civil and Commercial Matters (Recast 2002) O.J. (L 12) (EC), art. 27.

${ }^{41}$ See, e.g., Furmston 2015.

42 Council Regulation 1215/2012, on Jurisdiction and the Recognition and Enforcement of Judgments in Civil and Commercial Matters (Recast 2002) O.J. (L 12) (EC), art. 1(2)(d).
} 


\section{Microsoft v. Motorola}

In Microsoft v. Motorola, Microsoft alleged that Motorola breached its commitment to grant licenses on RAND terms under SEPs relating to two industry standards, ITU's H.264 and IEEE's 802.11 Wi-Fi. ${ }^{43}$ Microsoft brought a breach of contract claim against Motorola in the U.S. District Court for the Western District of Washington. At roughly the same time, Motorola brought a patent infringement action against Microsoft in the Mannheim Regional Court in Germany seeking to enjoin Microsoft's sale of allegedly infringing Xbox and laptop computer products under its H.264 SEPs. ${ }^{44}$ As discussed in Chapter 25, German courts typically adjudicate issues of injunctive relief on an accelerated basis, prior to determinations of infringement and validity. Accordingly, the Mannheim Court enjoined Microsoft from selling the allegedly infringing products in Germany. ${ }^{45}$ In response, Microsoft sought an anti-suit injunction in the U.S. district court to prevent Motorola from enforcing the German court's injunction. ${ }^{46}$

The U.S. court granted Microsoft's anti-suit injunction. Applying the liberal approach, the court determined first that the parties were the same in both the U.S. breach of contract matter and the German infringement matter; and second, that the resolution of the U.S. breach of contract claim would be dispositive of the German infringement action. ${ }^{47}$ It was of particular importance that Motorola's commitment to ITU required Motorola to grant Microsoft a worldwide license under all of Motorola's relevant SEPs, including the ones disputed in the German case. ${ }^{48}$ Turning to the five factors, the court noted that at least two of factors favored granting the anitsuit injunction. First, the condensed timeline between the initiation of the United States and the German cases "raise[d] concerns of forum shopping and duplicative and vexatious litigation." ${ }^{49}$ Second, maintaining the parallel German infringement action raised concerns of inconsistent judgments. ${ }^{50}$

Motorola appealed the grant of the anti-suit injunction to the U.S. Court of Appeals for the Ninth Circuit. On appeal, Motorola argued that the U.S. breach of contract action would not necessarily resolve the German infringement action. ${ }^{51}$ Specifically, Microsoft's breach of contract claim focused on whether Motorola's initial royalty offer breached its RAND assurance to ITU, and the court would not necessarily establish a worldwide license and royalty. ${ }^{52}$ As such, the resolution of the U.S. action would not be dispositive the German action, and concerns of vexatious litigation and prejudice were not implicated. ${ }^{53}$ However, the Ninth Circuit affirmed the district court's grant of the anti-suit injunction. ${ }^{54}$ Citing the terms of Motorola's commitment to ITU, the court reasoned that "the face of the contract makes clear that it encompasses not just U.S. patents, but all of Motorola's standard-essential patents worldwide." ${ }^{55}$ Therefore, regardless of how the RAND royalty was ultimately calculated, Motorola's contractual

${ }^{43}$ Microsoft Corp. v. Motorola, Inc. (W.D. Wash. 2012, p.1093).

${ }^{45}$ Id. at 1096 .

${ }^{46} / d$.

${ }^{47}$ Id. at 1098. Microsoft's argued, and the court agreed, that if Motorola were found in the U.S. case to have breached its RAND obligation to the relevant SDOs, then Motorola would not be entitled to seek injunctive relief against Microsoft in any jurisdiction under the patents that it should have licensed to Microsoft.

${ }^{48}$ Id. at 1099.

${ }^{49}$ Id. at 1100 .

${ }^{50}$ Id.

51 Opening Brief of Defendants-Appellants at 25, Microsoft Corp. v. Motorola, Inc. (9th Cir. 2012, p.884) (anti-suit injunction case).

52 ld. at $25-27$.

${ }^{53} \mathrm{Id}$. at 25-31.

${ }_{55}^{54}$ Microsoft Corp. v. Motorola, Inc. (9th Cir. 2012, p.884) (anti-suit injunction case).

${ }^{55} \mathrm{Id}$. 
commitment was incompatible with seeking an injunction banning sales abroad. ${ }^{56}$ Consequently, the Ninth Circuit held that the district court did not abuse its discretion in granting the anti-suit injunction.

\section{Vringo v. ZTE}

Vringo v. ZTE involved patents essential to ETSI's 2G, 3G, and 4G wireless telecommunications standards. Vringo purchased a group of SEPs covering these standards from Nokia, but acknowledged its obligation to grant "licenses to practice [the] essential patents on fair, reasonable, and nondiscriminatory ("FRAND") terms and conditions." ${ }^{\text {"FT }}$ ZTE manufactures telecommunications infrastructure equipment that allegedly infringed some of these SEPs. ${ }^{58}$ In October of 2012, Vringo brought patent infringement actions against ZTE around the world. ${ }^{59}$ The parties soon began settlement negotiations and entered into a mutual non-disclosure agreement (NDA). When settlement talks deteriorated, ZTE filed an antitrust suit in Shenzhen, China, claiming Vringo's failure to license its SEPs on FRAND term was an abuse of its market position. ${ }^{60}$ To support its claim, ZTE included information that was exchanged between the parties and allegedly protected under the NDA. In response, Vringo brought a breach of contract claim in the U.S. District Court for the Southern District of New York and sought an anti-suit injunction to "require ZTE to withdraw its Shenzhen complaint and enjoin it from pursuing the same or similar claims in that court or any other court in the Guangdong Province." 61

The U.S. court declined to issue the anti-suit injunction, reasoning that the applicable threshold criteria were not satisfied. Although the parties to the two suits were the same, the court noted that "[a] decision holding that ZTE breached the NDA would not necessarily foreclose the antitrust action in the Shenzhen court." ${ }^{62}$ Specifically, although "ZTE uses Vringo's highly confidential opening offer as the basis for its claims ... it does not foreclose the possibility that ZTE provided or will provide the Shenzhen court with other evidence and reasons from which it could conclude that Vringo abused its market position." ${ }^{63}$ On this basis, the court rejected Vringo's motion for an anti-suit injunction.

\section{TCL v. Ericsson}

In TCL v. Ericsson, ${ }^{64} \mathrm{TCL}$ filed a breach of contract claim in the United States District Court for the Central District of California alleging that Ericsson breached its obligation to license certain SEPs covering ETSI's $2 \mathrm{G}, 3 \mathrm{G}$ and $4 \mathrm{G}$ standards to TCL on FRAND terms. ${ }^{65}$. TCL also sought an anti-suit injunction to prevent Ericsson from maintaining patent infringement actions against TCL under corresponding patents in France, Brazil, Russia, the UK, Argentina, Germany, and the Eastern District of Texas. ${ }^{66}$

The district court in California distinguished the foreign and domestic lawsuits based on the patents being asserted - SEPs versus non-essential implementation patents - and granted an anti-suit injunction only against the foreign lawsuits. In analyzing the rationale for issuing the

${ }^{56}$ Id. at 885 .

${ }^{57}$ Vringo, Inc. v. ZTE Corp. (S.D.N.Y. June 3, 2015, p.*1).

${ }^{58} \mathrm{Id}$.

${ }^{59} l d$.

${ }^{60}$ Id. at ${ }^{*} 2$.

${ }^{61}$ Id. at ${ }^{* 11}$.

62 ld.

${ }^{63} / d$.

${ }^{64}$ TCL Commc'n Tech. Holdings, Ltd. v. Telefonaktienbolaget LM Ericsson et al. (C.D. Cal. 2015).

${ }^{65}$ ORDER re Motions, TCL Commc'n Tech. Holdings, Ltd. v. Telefonaktienbolaget LM Ericsson et al. (C.D. Cal. 2015).

${ }^{66}$ Id. at $5-8$. 
foreign anti-suit injunction, the court applied the liberal standard, noting that a "bilateral preliminary anti-suit injunction is warranted based on the parties' mutual agreement." 67 The court acknowledged that the parties were the same in both the California breach of contract action and the foreign patent infringement actions, and that the parties "both indicated their desire that this action should result in a 'global resolution' of the SEP patent licensing and damages claims."68

Conversely, the court rejected TCL's request for a domestic anti-suit injunction. The court noted that Ericsson's infringement action in the Eastern District of Texas centered around Ericsson's non-SEP implementation patents, which were not, by definition, subject to Ericsson's FRAND commitments made at ETSI. Thus, the infringement action in Texas could not be resolved by the outcome of the FRAND litigation in California, eliminating any basis for issuing an anti-suit injunction to prevent the maintenance of the Texas action." 69

\section{Agency Orders with Global Effect}

Though, strictly speaking, they are not judicial anti-suit injunctions, it is worth noting that antitrust enforcement agencies have also begun to issue remedial orders with global effect in SEP-related cases. For example, in the consent decree settling the U.S. Federal Trade Commission (FTC) investigation of Google-Motorola, Google agreed not to seek injunctive relief against infringers of its SEPs anywhere in the world until it exhausted certain prescribed

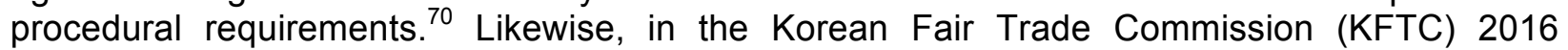
remedial order against Qualcomm, the KFTC ordered Qualcomm to cease certain licensing practices with respect to firms that are headquartered in Korea, sell products in Korea or supply components to sellers of products in Korea. ${ }^{71}$ The scope of this order thus extends well beyond the borders of Korea.

\section{Conclusions}

Given the global nature of much SEP litigation, anti-suit injunctions can serve as valuable tools for containing litigation costs and avoiding inconsistent and incompatible outcomes across jurisdictional borders. Anti-suit injunctions allow a prospective SEP licensee to focus its resources on a single forum without the threat of faster-moving suits in other countries. This mechanism also ensures that contractual FRAND disputes will be resolved based on their merits before injunctions are issued on the basis of an incomplete record. As such, anti-suit injunctions can help litigants avoid inequities arising from forum shopping across jurisdictions, particularly when some jurisdictions are likely to proceed rapidly to grant remedies such as injunctive relief before related issues are fully resolved elsewhere.

\footnotetext{
${ }^{67} / d$. at 11.

${ }^{68} \mathrm{Id}$.

${ }^{69} / d$. at 9 .

70 In re. Motorola Mobility and Google 2013.

${ }^{71}$ See Chapter 19, discussing the KFTC order in greater detail. As of this writing, Qualcomm has appealed the order.
} 


\section{The Anti-Suit Injunction}

\section{REFERENCES}

Ali, Arif, Katherine Nesbitt, and Jane Wessel. 2008. "Anti Suit Injunctions in Support of International Arbitration in the United States and the United Kingdom," International Arbitration Law Review 12.

Barceló, John J. 2007. "Anti-Foreign-Suit Injunctions to Enforce Arbitration Agreements," Cornell Law Sch. Legal Stud. Res. Paper Series, October 17, 2007.

Bermann, George A. 1990. "The Use of Anti-Suit Injunctions in International Litigation," 28 Columbia Journal of Transactional Law 589.

China Trade and Dev. Corp v. M. V. Choong Yong, 837 F.2d 33 (2d Cir. 1987).

Cole v. Cunningham, 133 U.S. 107 (1890).

Council Regulation 1215/2012, on Jurisdiction and the Recognition and Enforcement of Judgments in Civil and Commercial Matters (Recast 2002) O.J. (L 12) (EC), art. 27.

Council Regulation 44/2001, on Jurisdiction and the Recognition and Enforcement of Judgments in Civil and Commercial Matters 2001 O.J. (L 12) (EC), art. 27.

de Coale, Margarita Trevino. 1999. "Stay, Dismiss, Enjoin, or Abstain?: A Survey of Foreign Parallel Litigation in the Federal Courts of the United States," 17 Boston University International Law Journal 79.

E. \& J. Gallo Winery v. Andina Licores S.A., 446 F.3d 984 (9th Cir. 2006).

Furmston, Olivia. 2015. "Anti-suit injunctions - are they still a useful remedy in the UK?," Standard Bulletin Defense Special Edition, Oct. 2015.

Gage v. Riverside Trust Co., 86 F. 984, 986 (C.C.S.D. Cal. 1898).

Gazprom OAO v. Lietuvos Respublika (CJEU 2015).

Goss Int'l Corp. v. Man Roland Druckmaschinen Aktiengesellschaft, 491 F.3d 355 (8th Cir. 2007).

Hartley, Trevor C. 2015. International Commercial Litigation. Cambridge: Cambridge University Press.

Helmholz, Richard H. 1975. "Writs of Prohibition and Ecclesiastical Sanctions in English Court Christian," 60 Minnesota Law Review 1011

Hilton v. Guyot, 159 U.S. 113 (1895).

Hope v. Carnegie (1866) 1 Ch.App. 320.

Lord Portarlington v. Soulby (1834) 3 My \& K. 104, 40 Eng. Rep. 40.

Merial Ltd. v. Cipla Ltd., 681 F.3d 1283 (Fed. Cir. 2012).

Microsoft Corp. v. Motorola, Inc., 696 F.3d 872 (9th Cir. 2012).

Microsoft Corp. v. Motorola, Inc., 871 F. Supp. 2d 1089 (W.D. Wash. 2012).

In re Motorola Mobility, LLC \& Google, Inc., No. 1210120 (F.T.C. 2013).

Nanda, Ved P. et al. 2017. Litigation of International Disputes in U.S. Courts. Thomson Reuters.

Peck v. Jenness, 48 U.S. (7 How.) 612 (1849).

Princess Lida of Thurn \& Taxis v. Thompson, 305 U.S. 456 (1939).

Quaak v. Klynveld Peat Marwick Goerdeler Bedrijfsrevisoren, 361 F.3d 11 (1st Cir. 2004).

Raushenbush, Richard W. 1985. "Antisuit Injunctions and International Comity," 71 Virginia Law Review 1039.

Seattle Totems Hockey Club, Inc. v. Nat'l Hockey League, 652 F.2d 852 (9th Cir. 1981).

Shaknes, Alexander. 2008. "Anti-Suit and Anti-Anti-Suit Injunctions in Multi-Jurisdictional Proceedings," 21 International Law Practicum 96.

Tan, Daniel. 2005. "Anti-Suit Injunctions and the Vexing Problem of Comity," 45 Virginia Journal of International Law 283.

TCL Commc'n Tech. Holdings, Ltd. v. Telefonaktienbolaget LM Ericsson et al. (C.D. Cal. 2015).

In re Van Geuns, 946 F.2d 845 (Fed. Cir. 1991).

Vringo, Inc. v. ZTE Corp., No. 14-CV-4988 LAK, 2015 WL 3498634 (S.D.N.Y. June 3, 2015). 